\title{
Inhibitory effects of indirubin derivative PHII-7 on invasion and migration in metastatic cancers
}

\author{
X. GAO ${ }^{1}$, Y. ZHOU ${ }^{2}$, K. X. WU' 2 , Y. H. DING ${ }^{1}$, D. M. FAN ${ }^{1}$, M. YANG ${ }^{1}$, Y. Z. ZHANG ${ }^{2}$, Y. J. ZHANG ${ }^{1}$, D. S. XIONG ${ }^{1, *}$ \\ ${ }^{1}$ State Key Laboratory of Experimental Hematology, Institute of Hematology and Hospital of Blood Diseases, Chinese Academy of Medical Sciences \\ and Peking Union Medical College, Tianjin 300020, China; ${ }^{2}$ Central hospital of Karamay, Karamay, Xinjiang 834000, China
}

${ }^{*}$ Correspondence: dsxiong@hotmail.com

Received July 9, 2014 / Accepted August 26, 2014

\begin{abstract}
PHII-7, a derivative of indirubin, showed significant anti-cancer activities in vivo and in vitro. We asked whether treating human metastatic cancers and multidrug resistant cancer with PHII-7 would inhibit their invasion and migration. Cell growth was tested by MTT assay and colony formation assay. Apoptosis was examined by flow cytometry. Transwell-based assay and wound healing assay were used to examine cell invasion and migration. Real-time PCR assay and western blot assay were performed to test gene expression on mRNA and protein level, respectively. Firstly, we confirmed that MCF-7/ ADR cells showed more invasive and migratory properties compared with MCF-7 cells which were associated with several EMT markers, such as E-cadherin, Slug and vimentin. Secondly, we found that slightly toxic doses of PHII-7 decreased the number of cells that invaded a model epithelial basement membrane and that migrated by switching the molecular signature of the cells from mesenchymal to epithelial. And PHII-7 significantly regulated expression of several epithelial-mesenchymal transition (EMT)-related genes, including E-cadherin, Slug, $\beta$-catenin and vimentin. Thirdly, compared with control, PHII-7 inhibited cell proliferation in a time- and dose-dependent manner. Higher doses of PHII-7 also induced apoptosis through activating PARP, caspase- 9 and caspase-3. PHII-7 significantly inhibited invasion and migration in both metastatic cancers and multidrug resistant cancer. Our results may provide several data for future application of PHII-7 on drug design and patients treatment.
\end{abstract}

Key words: PHII-7, invasion, migration, multidrug resistance, epithelial-mesenchymal transition

Most deaths of patients from breast cancer and lung cancer are due to tumor cell invasion and migration $[1,2]$. Cancer cells spread when they become like mesenchymal cells through a reversible process known as an epithelial-mesenchymal transition (EMT). They develop a molecular signature characteristic of mesenchymal cells, resist apoptosis (genetically directed self-destruction), lose their polar structure, invade the epithelial basement membrane and lymphatic vessels, and migrate to distant sites. The cells then revert to their epithelial state and colonize the distant sites [3-5]. On the other hand, most relapses of cancer are due to metastasized cells that resist anti-cancer drugs through a variety of mechanisms [6-9]. For example, P-glycoprotein prevents toxic levels of doxorubicin in metastatic MCF-7/ADR breast cancer cells by exporting the drug [10]. A mesenchyme-specific means for activating a PI3K/ Akt signaling pathway that prevents apoptosis is thought to protect metastatic H1650ER lung cancer cells from erlotinib
[11]. Although there have been many strategies to overcome invasion, migration or multidrug resistance in human cancers, little useful anti-cancer strategies have been found to treat with invasive or migratory multidrug resistant cancers effectively in clinical treatment. So it is necessary to find a useful active molecular background for treatment on invasion, migration and even invasive or migratory multidrug resistance.

The derivative PHII-7 (which resembles indirubin [Figure 1], the active agent of the traditional Chinese herbal medicine, Danggui Longhui Wan, used to treat human chronic myelogenous leukemia $[12,13])$ can overcome multidrug resistance effectively. By decreasing the level of P-glycoprotein in multidrug resistant cancers, PHII-7 allows an intracellular concentration of anti-cancer drugs sufficient to induce apoptosis [14]. Our primary objective was to determine whether treating human metastatic cancer cells with slightly toxic doses of PHII-7 would decrease their migration and invasion. We 


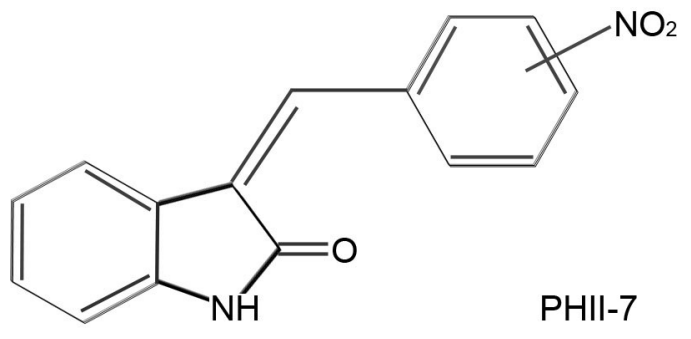

Figure 1. The chemical structure of PHII-7 and the specific location of -NO could not be published at present for the patent application.

used multidrug resistant breast cancer cell line MCF-7/ADR and human higher metastatic cancer cell line MDA-MB-231 and A549 as research models. Our second objective was to confirm that higher doses of PHII-7 would be toxic to these cells. And data showed that PHII-7 inhibited cell proliferation and induced apoptosis with higher doses. Our third objective was to investigate the mechanism of PHII-7 on invasion and migration. Results demonstrated that PHII-7 suppressed invasion and migration with lower doses effectively through regulating several EMT-related genes. PHII-7 is a valid derivative to restrain cell proliferation, invasion and migration in human cancers, especially for human metastatic multidrug resistant cancer. And results on the effects and mechanisms of PHII-7 can afford useful data for developing new anti-cancer drugs and treatments for multidrug resistance in the future.

\section{Materials and methods}

Materials. We designed and synthesized the derivative PHII-7, stored it as a $10 \mathrm{mg} / \mathrm{ml}$ DMSO stock, and diluted it with growth medium immediately before applying it to cells [15]. We obtained: polyclonal antibodies against Bax, GAPDH, caspase9, caspase3, and PARP from Cell Signaling Technology (Danvers, MA); Apoptosis Assay Kit from Becton Dickinson; Power SYBR Green PCR Master Mix from Applied Biosystems (Life Technologies); Matrigel, dimethyl sulfoxide (DMSO), and 3-(4, 5-dimethylthiazol-2-yl)-2, 5-diphenyl-2H-tetrazolium bromide (MTT) from Sigma-Aldrich; the breast adenocarcinoma cell line Michigan Cancer Foundation-7 (MCF-7), which has several traits of differentiated mammary epithelium, and the multidrug resistant breast cancer cell line MCF-7/ADR, which resists the anti-cancer drug doxorubicin (adriamycin), from Dr. Kenneth H. Cowan (National Cancer Institute, NIH, Bethesda, MD).

Cell culture. All four human cancer cell lines used in this study (M.D. Anderson metastatic breast adenocarcinoma [MDA-MB-231], alveolar non-small cell lung carcinoma [A549], MCF-7, and MCF-7/ADR) were maintained at $37^{\circ} \mathrm{C}$ and a humidified atmosphere of $5 \% \mathrm{CO}_{2}$ in growth medium: Roswell Park Memorial Institute medium (RPMI-1640) supplemented with $10 \%$ fetal bovine serum. To select for MCF-7/ADR cells that were nearly 40 times more resistant to doxorubicin than MCF-7 cells, doxorubicin $(1 \mu \mathrm{g} / \mathrm{ml})$ was added to cultures of MCF-7/ADR cells until 2 weeks before the cells were exposed to experimental conditions. Cell density was adjusted every 3 days by separating the cells with $0.25 \%$ trypsin with $0.02 \%$ ethylenediaminetetraacetic acid (EDTA) in phosphate-buffered saline, then diluting them with fresh growth medium [14].

Cell proliferation assay. Cells $\left(1 \times 10^{4}\right.$ per well $)$ were subjected to experimental conditions 12 hours after they were distributed to 96-well plates. Those in the treatment group were exposed to PHII-7: subgroup $1(0.5,1,2,4,6,8$ or $10 \mu \mathrm{M})$ for 24 hours, subgroup $2(0.25,0.5,1,2,4,6$, or $8 \mu \mathrm{M})$ for 48 hours, and subgroup $3(0.25,0.5,1,2,4,6$, or $8 \mu \mathrm{M})$ for 72 hours. MTT $(20 \mu \mathrm{l}$ of a $5 \mathrm{mg} / \mathrm{ml}$ stock in PBS buffer) was then added to each well. Four hours later, the culture medium in each well was replaced with $100 \mu$ l of DMSO to dissolve purple formazan, the metabolic product of MTT. Light absorbed by purple formazan at $570 \mathrm{~nm}$, measured with a Synergy Hybrid Microplate Reader (Bio-Tek), was considered to be directly proportional to cell number.

Colony formation assay. Cells (100 per well) were subjected to experimental conditions 12 hours after they were applied to 6-well plates. Those in the treatment group were exposed to PHII-7 for 7 days: subgroup $1(0.1 \mu \mathrm{M})$ and subgroup 2 $(0.2 \mu \mathrm{M})$. During that interval, all cells received fresh growth medium, with or without PHII-7, every two days. Cells were then stained with crystal violet and the number of colonies with a diameter greater than $4 \mathrm{~mm}$ in each well was counted with aid of a light microscope [16].

Apoptosis assay. Cells $\left(1 \times 10^{5}\right.$ per well) applied to 6-well plates were subjected to experimental conditions when the wells became $70 \%$ confluent with cells. Those in the treatment group were exposed to PHII-7 for 48 hours: A549 and MDA-MB-231 cells $(1,3$, or $5 \mu \mathrm{M})$ and MCF $7 /$ ADR cells $(0.5$, 1 , or $2 \mu \mathrm{M})$. Then cells were collected, washed three times with cold PBS, and examined for apoptosis. The Apoptosis Assay Kit was used according to the manufacturer's protocol to stain cells with fluorescently labeled annexin V (a protein that binds membrane phosphatidylserine) and PI (a fluorescent dye that binds to nucleic acids). Stained cells from each well were resuspended in $300 \mu \mathrm{l}$ of cold PBS and counted with an LSR II (Becton Dickinson) flow cytometry. Cells binding annexin $\mathrm{V}$ but not propidium iodide were considered to be apoptotic.

Invasion and migration assay. We considered cell migration and invasion in culture to be biomarkers of metastasis. Pores ( $8 \mu \mathrm{m}$ diameter) of filters in transwell chambers (Corning) were filled with a reconstituted epithelial basement membrane by dissolving matrigel in RPMI-1640 medium at $4^{\circ} \mathrm{C}$, adding $24 \mu \mathrm{g}$ matrigel to each filter, and warming the chambers to $37^{\circ} \mathrm{C}$ for 5 hours. Cells in the treatment group were pre-treated with PHII-7 for 24 hours: A549 and MDAMB-231 cells $(0.5,1$ and $2 \mu \mathrm{M})$ and MCF-7/ADR cells $(0.25$, 0.5 and $1 \mu \mathrm{M})$. Then cells were resuspended at $3.33 \times 10^{5}$ cells/ $\mathrm{ml}$ with RPMI-1640 medium. The assay apparatus comprised 
24-well plates, each well containing $700 \mu \mathrm{l}$ of growth medium and one transwell chamber containing $300 \mu \mathrm{l}$ of cells in FBSfree RPMI-1640 medium. Chamber filters coated with matrigel were used for invasion assays and uncoated filters were used for migration assays. After incubating the apparatus at $37^{\circ} \mathrm{C}$ for additional 24 hours, the chambers were dried, stained with crystal violet $(0.1 \%$ in PBS), and cells visible from the underside of the filters were counted as having invaded the matrigel or as having migrated across the filter.

Wound healing assay. Cells $\left(1 \times 10^{5}\right.$ per well $)$ applied to 6-well plates were subjected to experimental conditions when the wells became from 80 to $85 \%$ confluent with cells. After forming wound gaps between cells by drawing a pipette tip across the plate surface, cells were washed 3 times with cold PBS and exposed to PHII-7 for 24 hours: A549 and MDA-MB231 cells $(1$ and $2 \mu \mathrm{M})$ and MCF-7/ADR cells $(0.5$ and $1 \mu \mathrm{M})$. Healing was measured as the distance individual cells moved toward the center of the gap, evident from photographs of the wells taken at time $0 \mathrm{~h}$ and $24 \mathrm{~h}$.

Real-time PCR assay. TRIzol (Life Technologies) was used to extract total ribonucleic acid (RNA) from cells that had been exposed to PHII-7 for 24 hours. Extracted RNA was converted to deoxyribonucleic acid (DNA) by means of DNA primers and Moloney murine leukemia virus reverse transcriptase (Promega). The relative amount of resulting DNA was measured with real-time quantitative polymerase chain reactions (PCR) performed with SYBR Green qPCR SuperMix-UDG reagents (Life Technologies) and an IQ5 multi-color real-time PCR detection system (Bio-BAD). Samples were heated at $95^{\circ} \mathrm{C}$ for $1 \mathrm{~min}$, subjected to 40 cycles of $95^{\circ} \mathrm{C}$ for 5 seconds and $60^{\circ} \mathrm{C}$ for 40 seconds, then heated at $95^{\circ} \mathrm{C}$ for $1 \mathrm{~min}$ and at $60^{\circ} \mathrm{C}$ for $1 \mathrm{~min}$. GAPDH was used as a reference, and change in gene expression was analyzed by the IQ5 software.

These primers were used [17]:

vimentin forward5'-TTGAACGCAAAGTGGAATC-3' reverse 5'-AGGTCAGGCTTGGAAACA-3'

E-cadherin forward 5'-GTCACTGACACCAACGATAATCCT-3' reverse 5'-TTTCAGTGTGGTGATTACGACGTT-3'

$\beta$-catenin forward5'-GCTGATCTTGGACTTGATATTGGTG-3' reverse 5'-GTCCATACCCAAGGCATCCTG-3'

Slug forward5'-GCAGACGACGGGTCAGAT-3' reverse 5'-GACTGACCCGTCGTGACG-3'

GAPDH forward5'-GAAGGTGAAGGTCGGAGTC-3' reverse 5'- GAAGATGGTGATGGGATTTC-3'

Western blot assay. Cells were lysed with RIPA buffer containing $150 \mathrm{mM} \mathrm{NaCl}, 100 \mathrm{mM}$ Tris- $\mathrm{HCl}$ (pH 8.0), $1 \mathrm{mM}$ EDTA, $0.5 \%$ Triton X-100 and a protease inhibitor cocktail with PMSF on ice for at least 30 minutes. The concentration of total protein was determined with a Protein Assay Kit (Thermo Fisher Scientific). Following electrophoresis of protein $(100 \mu \mathrm{g} /$ lane) on a $12 \%$ polyacrylamide gel in Tris-glycine buffer, the protein was transferred in Tris-glycine buffer containing 20\% methanol to a polyvinylidene difluoride membrane (Millipore) pretreated with non-fat milk (5\% in PBS containing Tween20 detergent) at room temperature for 1 hour. Membranes coated with transferred protein were treated with primary antibodies to cell proteins at $4^{\circ} \mathrm{C}$ overnight, then with secondary antibodies at room temperature for 1 hour. Stocks of both primary antibodies and secondary antibodies were diluted from 1:1000-1:2000 before application to the membranes. Antibodies thereby bound to the membranes were visualized with an enhanced chemiluminescence detection system BeyoECL Plus (Beyotime Institute of Biotechnology).

Statistical analysis. Continuous variables were expressed as mean (SD). Comparisons using Student's $t$-test and one-way analysis of variance (ANOVA) were performed with GraphPad Prism software (GraphPad Software, Inc). For all tests, $P<0.05$ was considered to be statistically significant.

\section{Results}

MCF-7/ADR cells showed more migratory, invasive abilities and EMT characters compared with MCF-7 cells. MCF-7/ ADR cells were more motile than the less metastatic MCF-7 cells. Of 100,000 cells applied to an upper well, $49.33 \pm 5.13$ MCF-7/ADR cells were observed under microscope at each field and MCF-7 cells could not migrate through membrane pores during an incubation time of 24 hours. MCF-7/ADR cells also showed more invasive than MCF-7 cells. Of 100,000 cells applied to an upper well, $34.33 \pm 4.04$ MCF-7/ADR cells could be observed under microscope at each field while little MCF-7 cells invaded membrane pores filled with a membrane (Figure $2 \mathrm{~A}, \mathrm{~B}$ ).

Consistent with that observation, MCF-7/ADR cells display a mesenchymal molecular signature characteristic of metastatic epithelial cells that have an undergone an epithelialmesenchymal transition (Figure 2C, D). These cells have high levels of Slug and vimentin mRNA and protein and have low levels of E-cadherin mRNA and protein. There was little Ecadherin examined in MCF-7/ADR cells while there was little vimentin examined in MCF-7 cells. And Slug expression was increased $1.92 \pm 0.75$ fold in MCF-7/ADR cells compared with MCF-7 cells.

PHII-7 inhibits cell invasion and migration. We chose three metastatic cancer cell lines in this study: human epithelial breast cancer cell line MDA-MB-231, multidrug resistant breast cancer cell line MCF-7/ADR, and lung cancer cell line A549. Pretreatment of MCF-7/ADR and MDA-MB-231 cells with PHII-7 for 24 hours decreased their invasive activity in a dose-dependent manner, at doses that did not inhibit cell proliferation or survival. During 24 hour incubation, invasion by MCF-7/ADR cells pretreated with $1 \mu \mathrm{M}$ PHII-7 was inhibited by $67.07 \pm 1.40 \%$ and invasion by MDA-MB-231 cells pretreated with $2 \mu \mathrm{M}$ PHII-7 was inhibited by $90.00 \pm 1.47 \%$. Under the same conditions, invasion by A549 cells pretreated with $2 \mu \mathrm{M}$ PHII-7 was inhibited by $69.35 \pm 1.17 \%$ (Figure $3 \mathrm{~A}$ ).

Pretreatment of MDA-MB-231 cells, A549 cells and MCF-7/ ADR cells with PHII-7 for 24 hours decreased their migration in a dose-dependent manner, at doses that did not inhibit cell survival. During 24 hour incubation, migration of MCF-7/ 


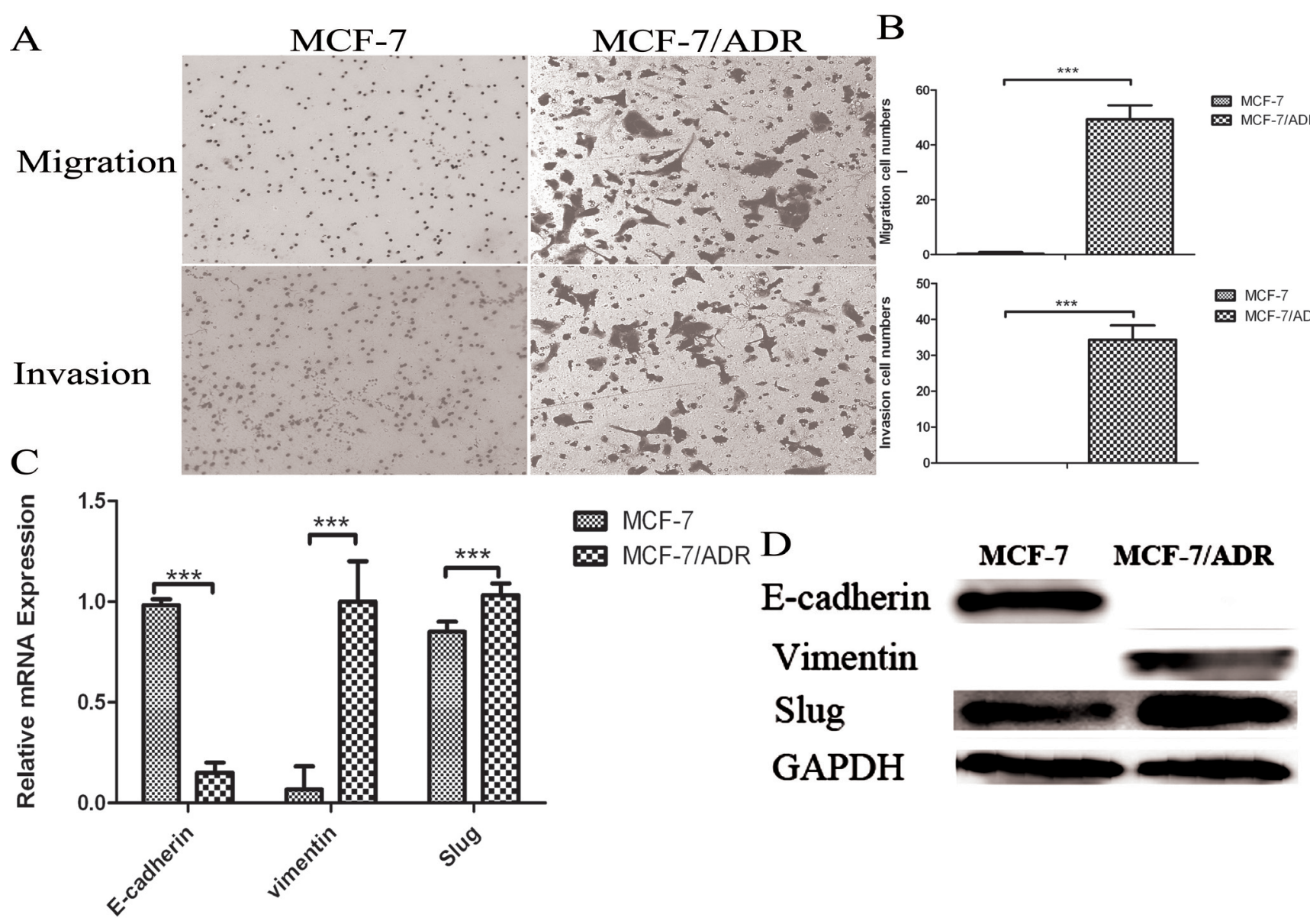

Figure 2. MCF-7/ADR cells showed more invasive, migratory abilities and EMT properties compared to MCF-7 cells. (A-B) Cells attached to transwell chambers were stained with crystal violet. Photographs of the underside of transwell assay were observed after 24 hours. (C-D) EMT-related gene expressions were tested by real-time PCR and western blot. Numerical analysis data represent mean \pm SD based on three independent experiments, ${ }_{* * *} P<\mathbf{0 . 0 0 1}$.

ADR cells pretreated with $1 \mu \mathrm{M}$ PHII-7 was inhibited by $79 \pm 2.18 \%$, MDA-MB-231 cells pretreated with $2 \mu \mathrm{M}$ PHII-7 was inhibited by $86.12 \pm 1.39 \%$. Migration of A549 cells was also inhibited by PHII-7 and inhibition ratio was $61.78 \pm 4.92 \%$ when exposed with $2 \mu \mathrm{M}$ PHII-7 for 24 hours (Figure 3B). The same qualitative pattern of migration was observed in a wound healing assay. Untreated MCF-7/ADR, MDA-MB-231 and A549 cells migrated into adjacent empty spaces during 24 hour incubation, but few cells pretreated with PHII-7 migrated (Figure 4).

PHII-7 regulated several EMT-related gene expressions. EMT process is closely associated with invasion and migration. In order to investigate the mechanism of PHII-7 on invasion and migration, we tested several EMT markers expressions. MCF-7/ADR, MDA-MB-231, and A549 cells treated with PHII-7 for 24 hours reverted in a dose-dependent manner to a molecular signature characteristic of metastatic epithelial cells. Levels of $\beta$-catenin, Slug, and vimentin mRNA and protein decreased and levels of E-cadherin mRNA and protein increased. When treated with $2 \mu \mathrm{M}$ PHII-7 in MDA-MB-231 cells, A549 cells and $1 \mu \mathrm{M}$ PHII-7 in MCF-7/ADR cells, there was little protein expressions of $\beta$-catenin, Slug, and vimentin. Moreover, there was more E-cadherin expression (Figure 5).

PHII-7 inhibits cell proliferation and colony formation. The dose of PHII-7 needed to limit MCF-7/ADR cell proliferation to half of that observed with untreated cells was $8.31 \pm 0.36 \mu \mathrm{M}$ for 24 hours, $2.79 \pm 1.13 \mu \mathrm{M}$ for 48 hours, and $0.86 \pm 0.11 \mu \mathrm{M}$ for 72 hours. The equivalent effective dose for MDA-MB-231 cells was $12.52 \pm 0.73 \mu \mathrm{M}$ for 24 hours, $5.21 \pm 1.13 \mu \mathrm{M}$ for 48 hours, and $2.37 \pm 0.82 \mu \mathrm{M}$ for 72 hours; and for A549 cells was $9.97 \pm 0.32 \mu \mathrm{M}$ for 24 hours, $4.74 \pm 0.28 \mu \mathrm{M}$ for 48 hours, and $1.47 \pm 0.17 \mu \mathrm{M}$ for 72 hours (Figure 6A).

A dose of $0.2 \mu \mathrm{M}$ PHII- 7 during 7 days of growth decreased the percentage of cell colonies of at least $4 \mathrm{~mm}$ in diameter to $93.82 \pm 2.74 \%$ of the control level for MDA-MB-231 cells, to $99.33 \pm 0.64 \%$ of the control level for MCF-7/ADR cells, and to $97.33 \pm 1.12 \%$ of the control level for A549 cells (Figure 6B). 


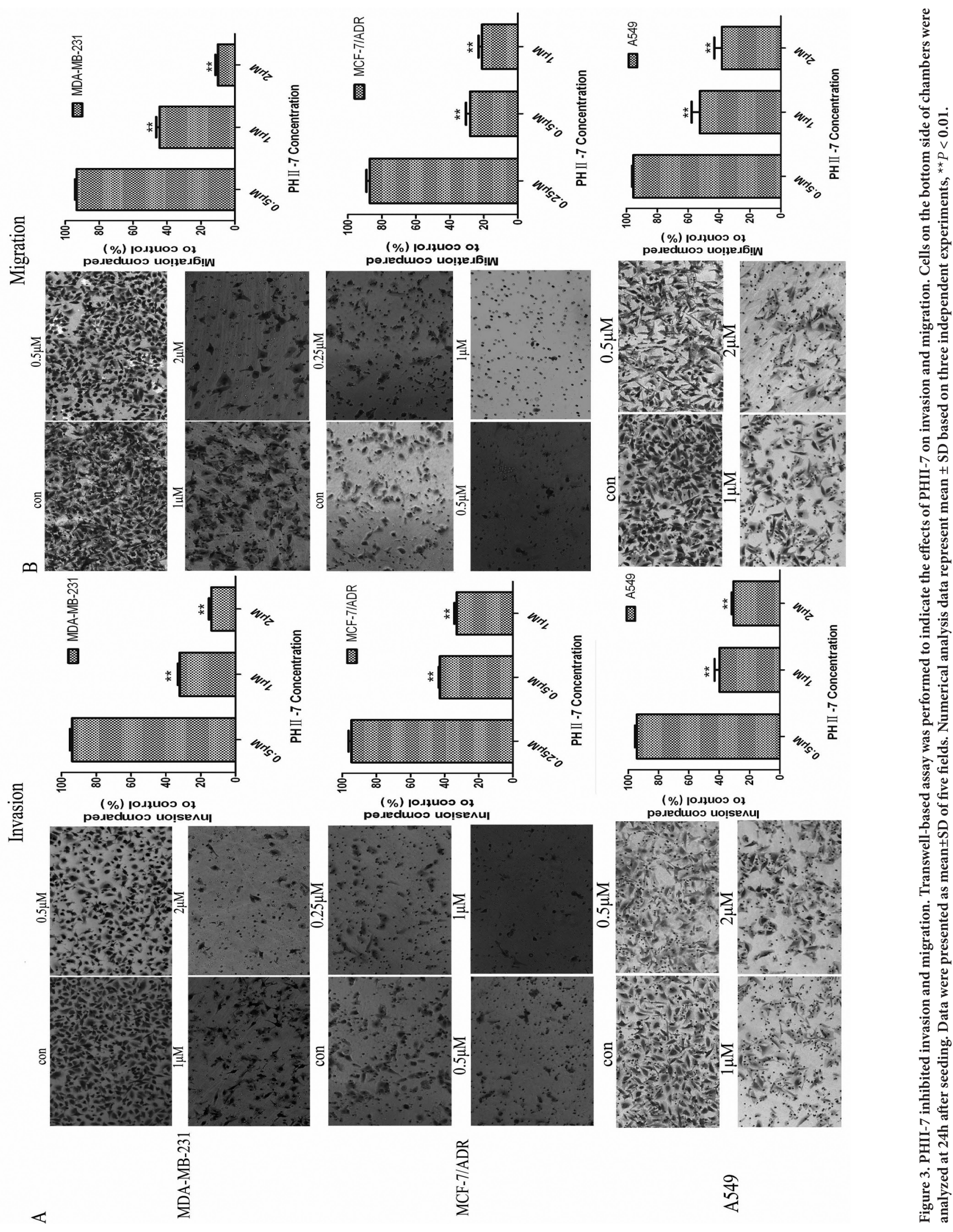




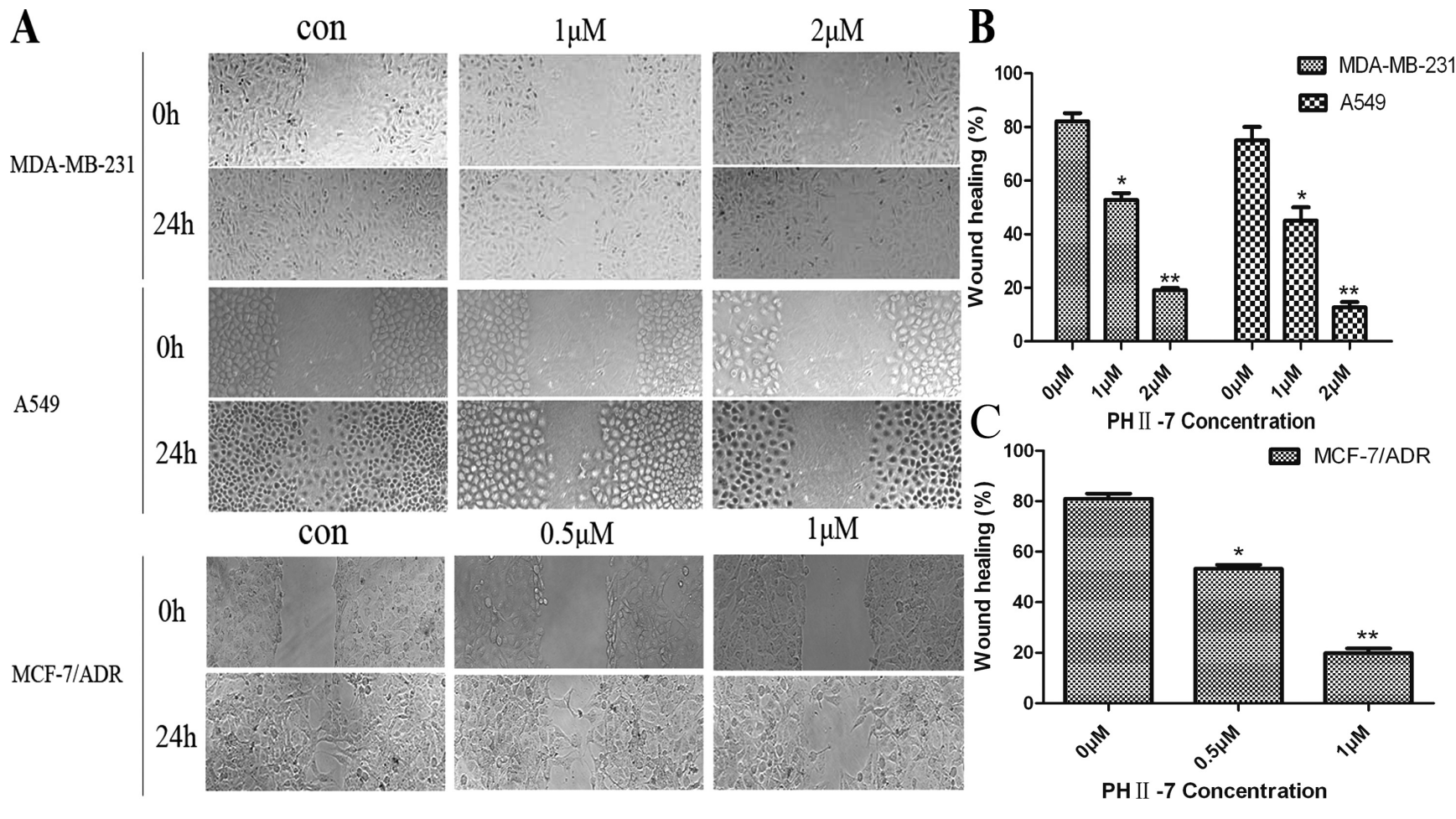

Figure 4. (A) Cell migration abilities were confirmed by wound healing assays. Confluent monolayer was scraped with the same tip and wound healings were assessed by observation under microscope after $24 \mathrm{~h}$. (B) (C) Numerical analysis data represent mean \pm SD based on three independent experiments, ${ }^{\star} \mathrm{P}<0.05 ;{ }^{\star} \mathrm{P}<0.01$.

PHII-7 induces apoptosis in a dose-dependent manner. In order to confirm that whether PHII-7 could induce apoptosis in metastatic cancers, we used flow cytometry assay and western blot assay to analyze. Results showed that treatment of MDA-MB-231 cells with PHII-7 for 48 hours increased the percentage of apoptotic cells to $2.97 \pm 0.15 \%(1 \mu \mathrm{M})$, $16.13 \pm 0.12 \%(3 \mu \mathrm{M})$, and $29.87 \pm 1.05 \%(5 \mu \mathrm{M})$. Treatment of MCF-7/ADR cells with PHII-7 for 48 hours increased the percentage of apoptotic cells to $10.73 \pm 0.31 \%(0.5 \mu \mathrm{M})$, $13.63 \pm 0.21 \%(1 \mu \mathrm{M})$, and $41.80 \pm 0.79 \%(2 \mu \mathrm{M})$. And treatment of A549 cells with PHII-7 for 48 hours increased the percentage of apoptotic cells to $13.60 \pm 3.20 \%(1 \mu \mathrm{M}), 32.47 \pm 0.75 \%(3 \mu \mathrm{M})$, and $49.20 \pm 3.44 \%(5 \mu \mathrm{M})$ (Figure 7A, B).

Likewise, treatment of MDA-MB-231, MCF-7/ADR and A549 cells with PHII-7 for 48 hours resulted in a dosedependent increase in the levels of proteins that participate in apoptosis: Bax, cleaved caspase 3, cleaved caspase 9 , and cleaved PARP (Figure 7C, D). These activated genes confirmed that PHII-7 induced apoptosis through the canonical mitochondrial apoptotic pathway.

\section{Discussion}

Breast cancer and lung cancer are the most common neoplasms all over the world and when cells exhibited invasion, migration or drug resistance it becomes hard to cure [18-20]. Invasion and metastasis are two modes of cancer dissemination, and active migration of cancer cells is a requirement for invasion and metastasis. Additionally, several multidrg resistant cancers showed metastatic properties, and these feathers afford more hinders on treatments $[11,21,22]$. Invasion and migration are also associated with epithelial-mesenchymal transition (EMT). During EMT process cells lose epithelial characters and get mesenchymal characters $[23,24]$. Data demonstrated that EMT process is also associated with multidrug resistance in MCF-7/ADR cells [25]. For example, Twist, one of the EMT markers, is related to multidrug resistance and invasion [26]. We firstly confirmed that MCF-7/ ADR cells showed more invasive and migratory properties compared with MCF-7 cells by transwell assay and wound healing assay. Here, we also demonstrated that invasive and migratory properties of MCF-7/ADR were related to not only E-cadherin but also Slug, vimentin and $\beta$-catenin which were major EMT markers.

Indirubin is the active constituent of traditional Chinese medicine Danggui Longhui Wan and shows multifunctions in anti-cancer treatments [27]. PHII-7, a derivative of indirubin, also inhibited cell growth in vitro and in vivo in a range of cancers, such as leukemia $[14,15]$. Moreover, PHII-7 can act as a chemo-sensitizer by increasing sensitivity of multidrug 


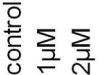
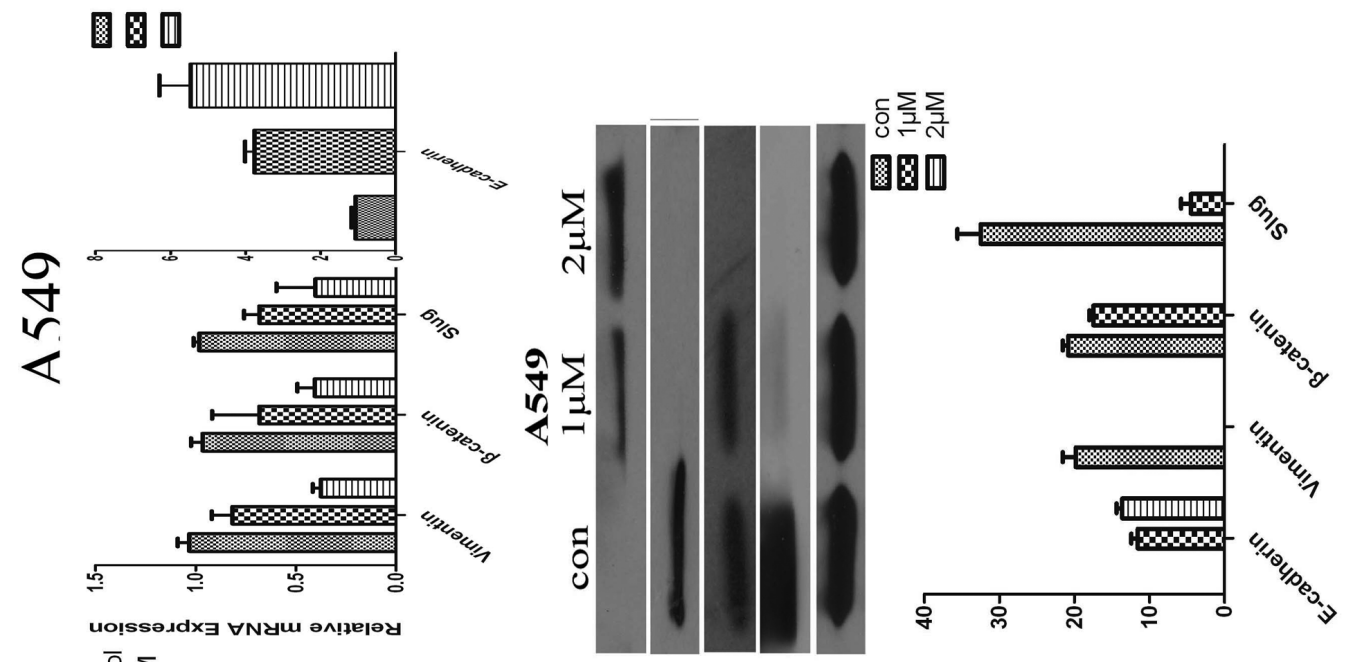

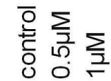
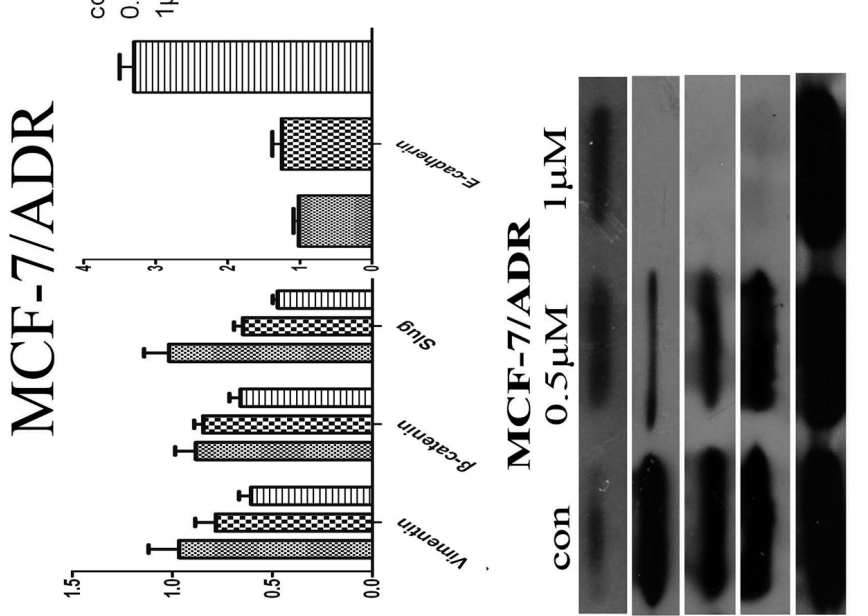

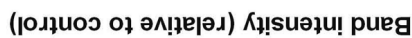

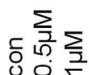

ڤั

:

uolssaddx $\forall$ NyUu an!nejay 은

이이리

圆圆

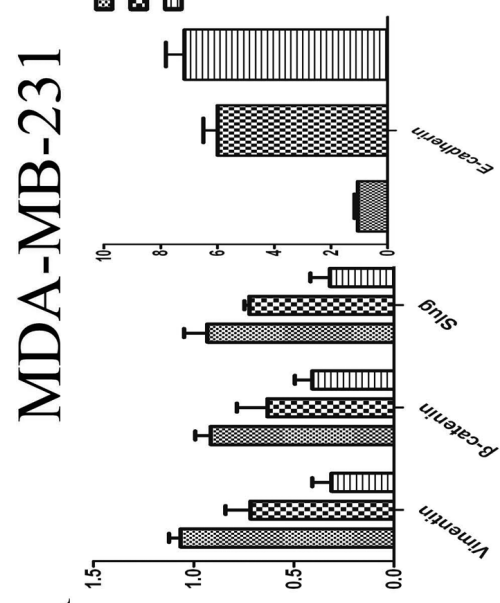

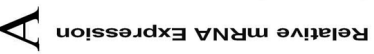

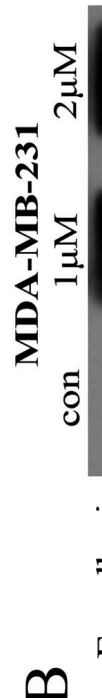

圆四

원

安

焉

露

造

状

ㄴ.

类

范

近

年

咅里

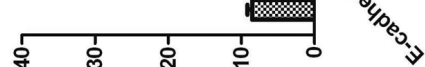

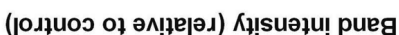

סำ

80

ธี

品

要

家

을

融

हैं

ํํㄴ

i

i

苞

悹

远

总

논

实

in 

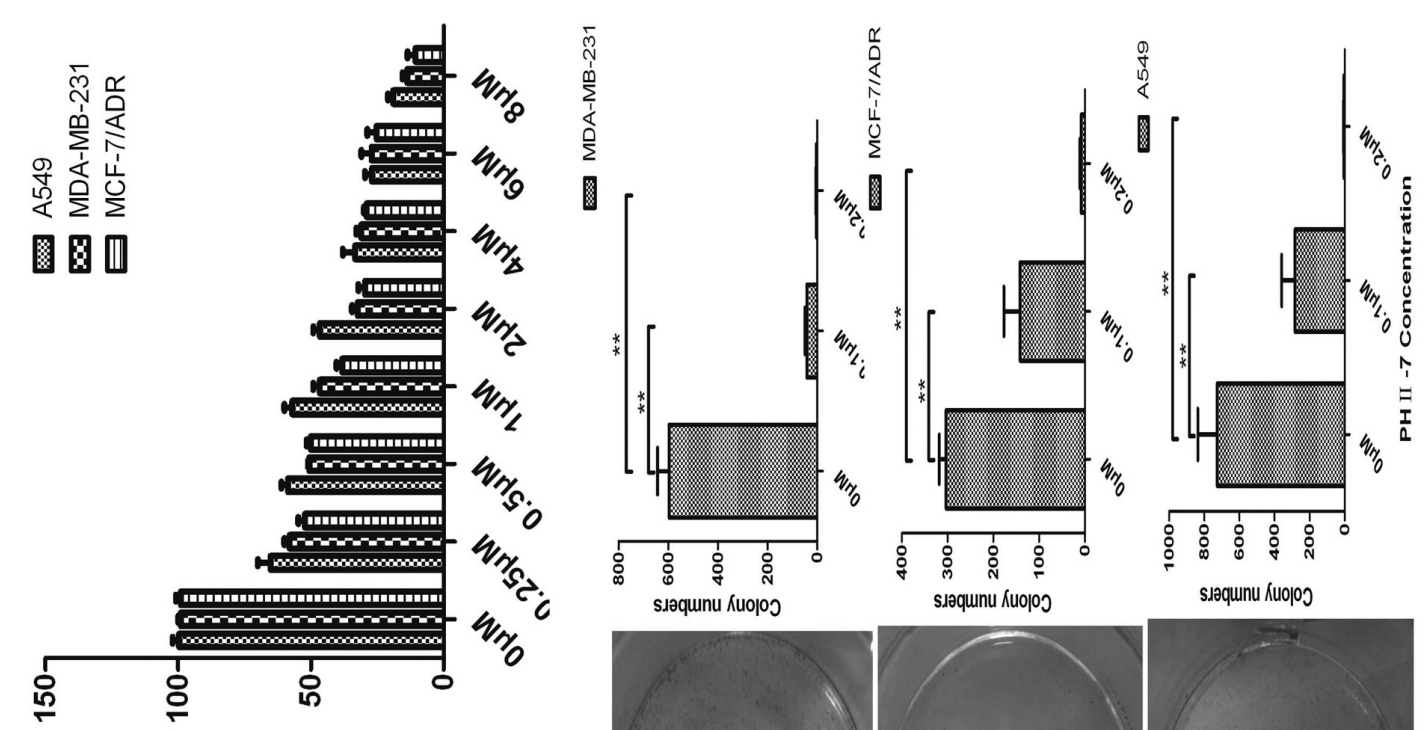

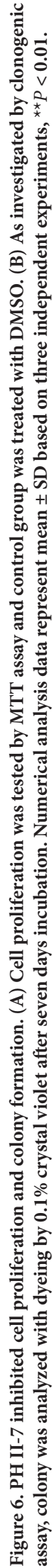

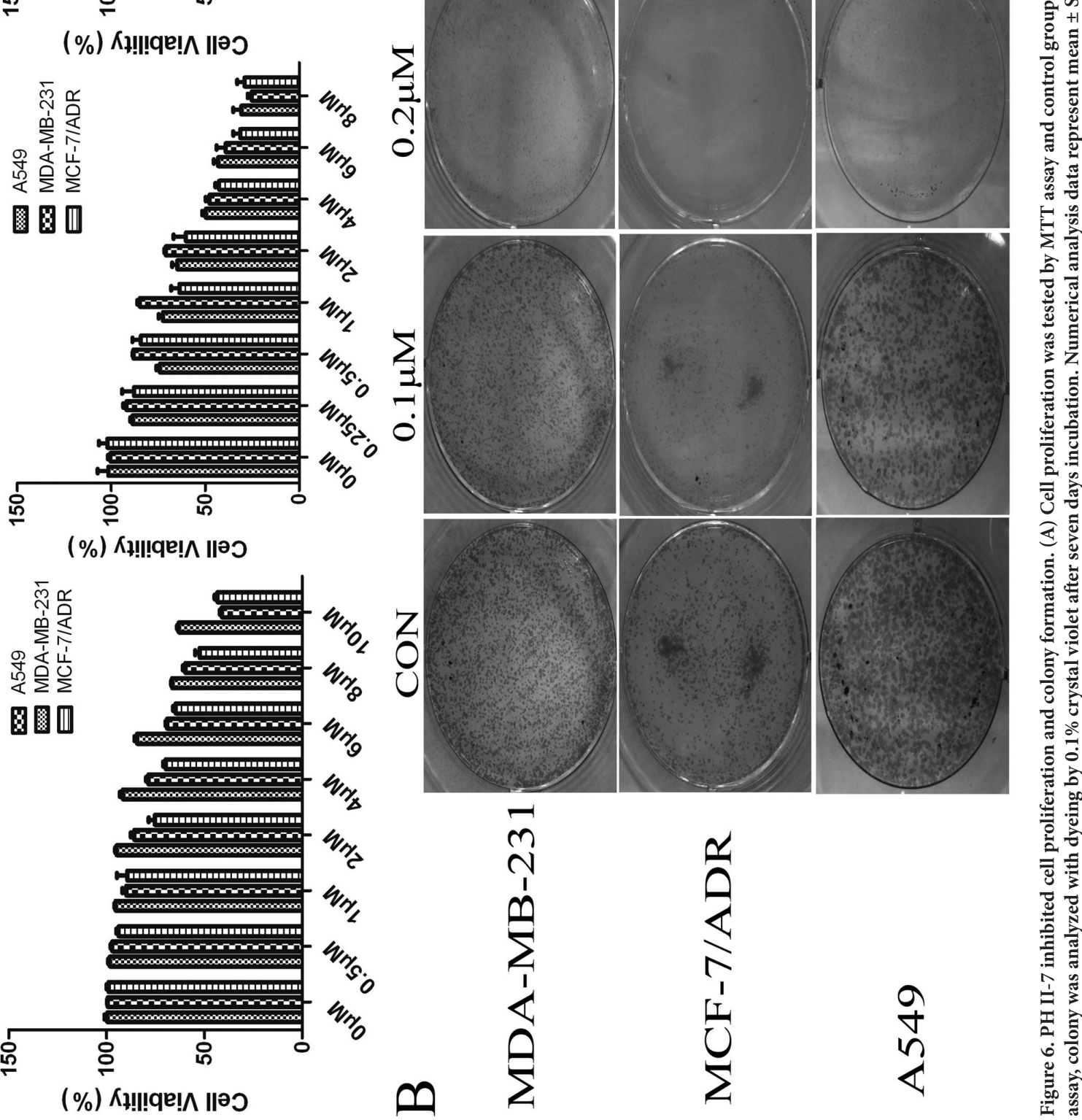


A

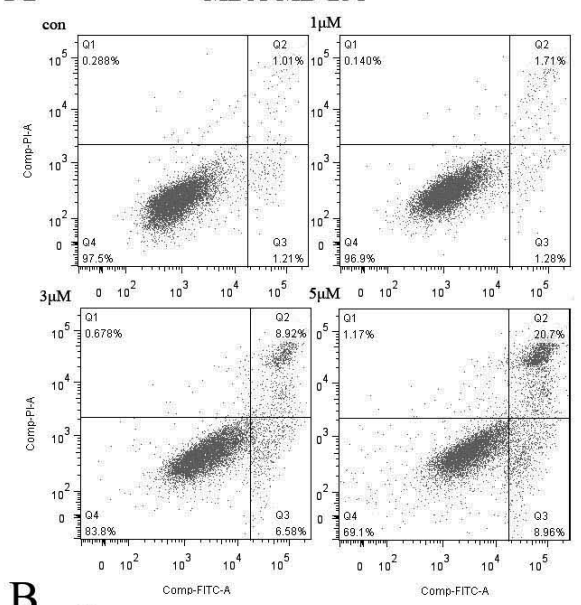

B

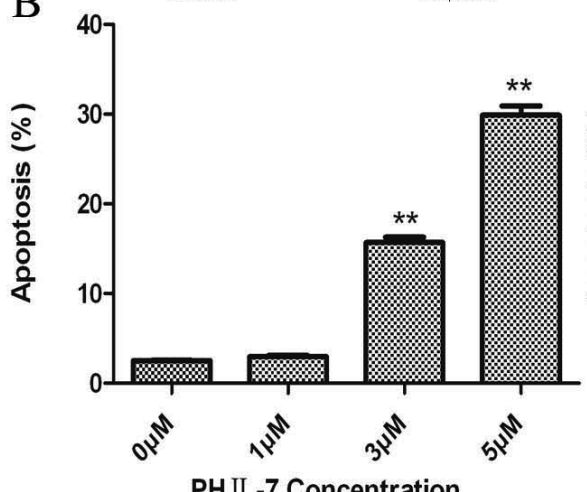

PH II -7 Concentration

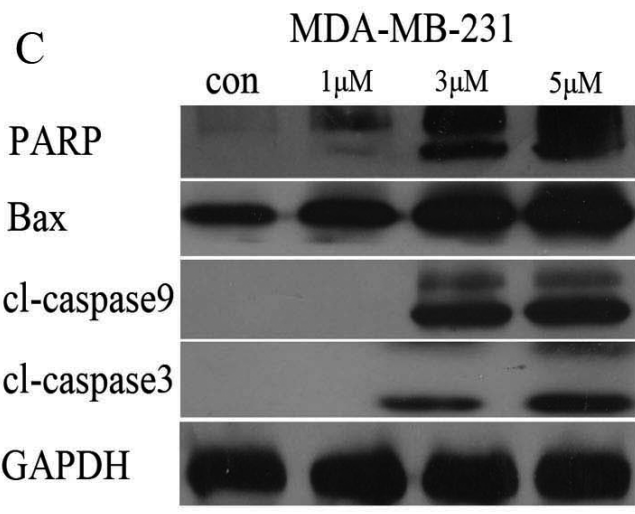

D

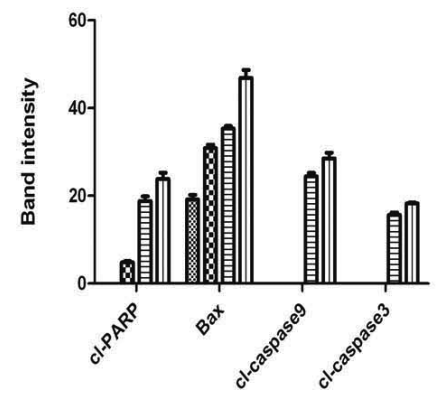

MCF-7/ADR
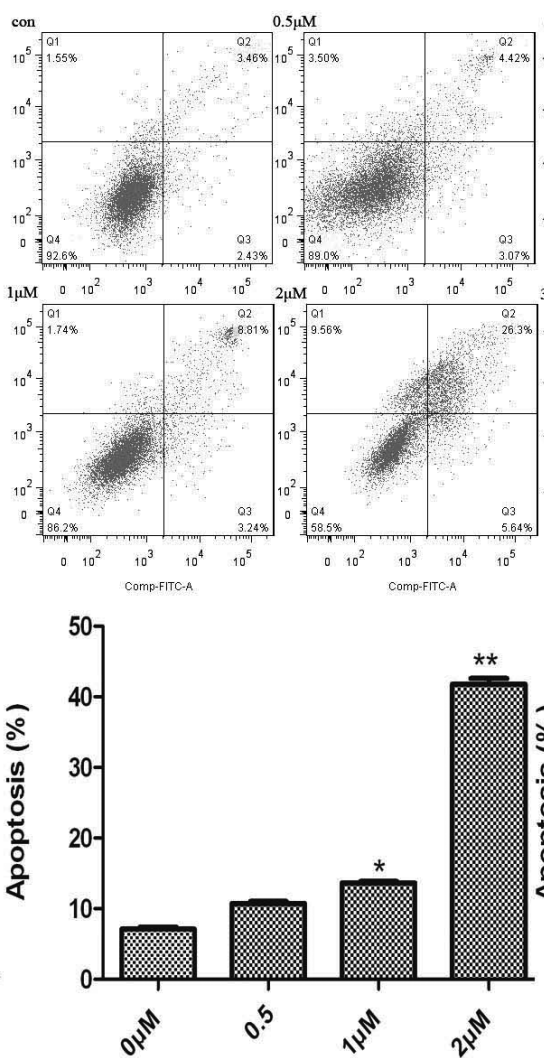

PH II -7 Concentration

MCF-7/ADR
A549
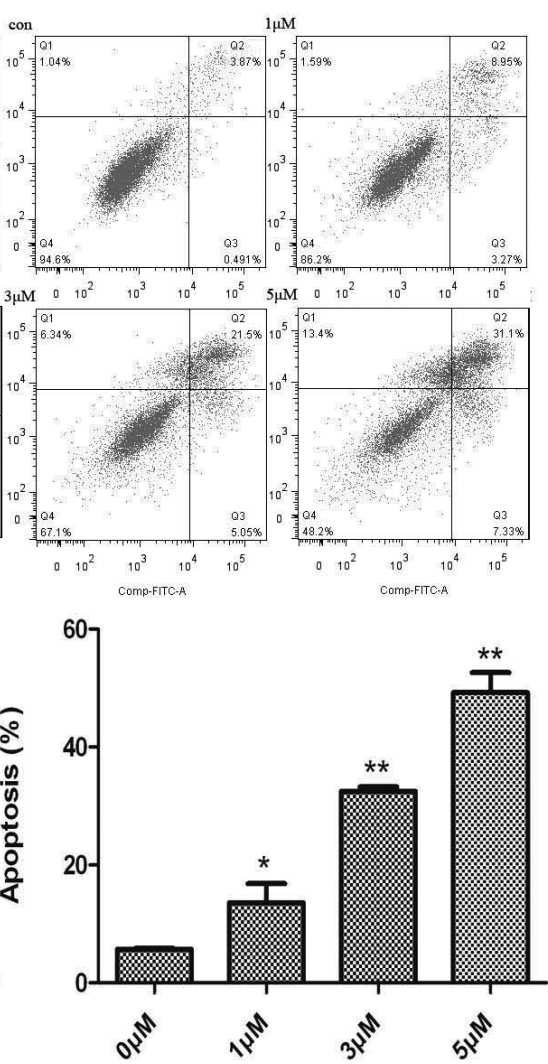

PH II -7 Concentration

A549

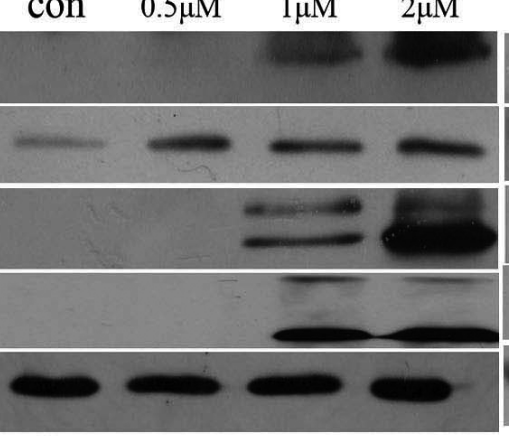

con $\quad 1 \mu \mathrm{M} \quad 3 \mu \mathrm{M} \quad 5 \mu \mathrm{M}$
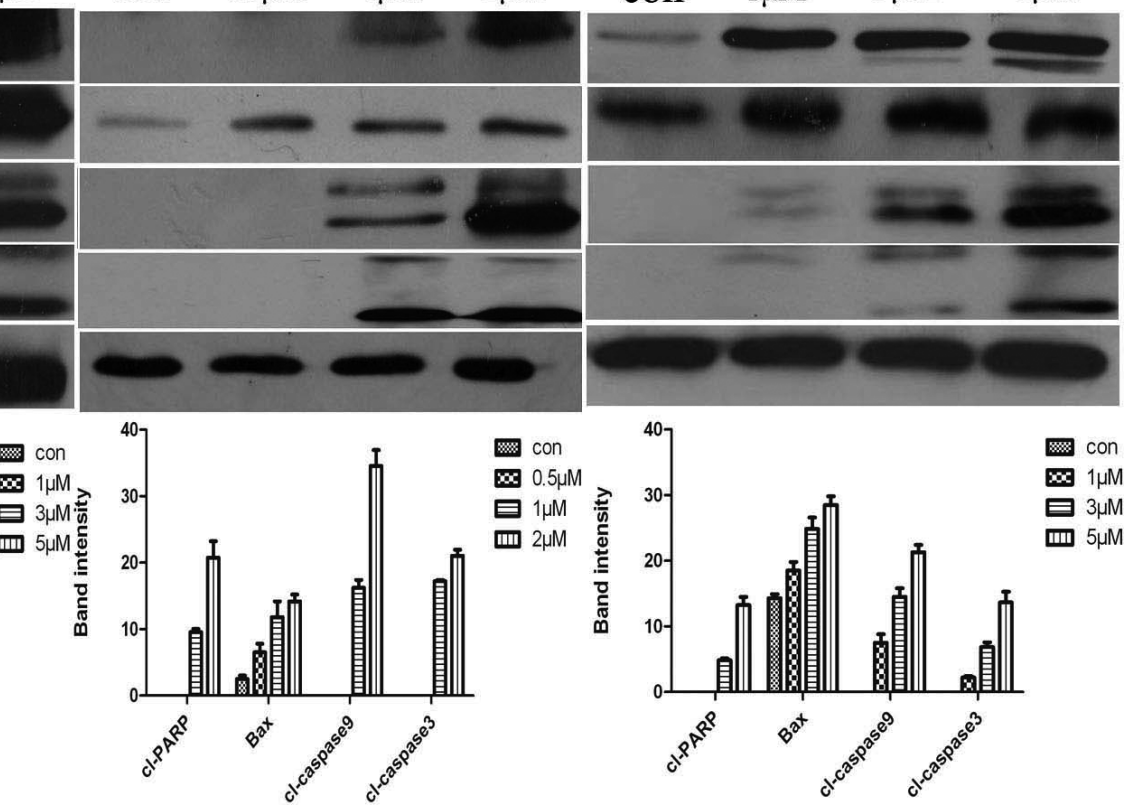

Figure 7. PHII-7 induced apoptosis in a dose-dependent manner. (A-B) Apoptosis in MDA-MB-231 cells were tested and analyzed by flow cytometry and FlowJo 7.6 software. (C-D) Western blot showed the expressions of apoptosis-related genes, including cl-PARP, cl-caspase9, cl-caspase3 and Bax. PHII-7 induced apoptosis with caspase-related cascade. Band intensities were analyzed with Quantity One software compared with GAPDH. Numerical analysis data represent mean \pm SD based on three independent experiments, ${ }^{\star} P<0.05 ;{ }^{* *} P<0.01$. 
resistant cancers to drugs. In this study, we focused the effects of PHII-7 on invasion and migration in human multidrug resistant cancer and higher metastatic cancers. We found that three metastatic human epithelial cancer cell lines became less motile in vitro when treated with slightly toxic doses of PHII-7, regardless of whether they resisted other anti-cancer drugs. These breast, multidrug resistant and lung cancer cells less frequently invaded a model basal epithelial membrane and less frequently migrated across pores in transwell chambers. PHII-7 regulated several EMT-related gene expressions, including E-cadherin (a transmembrane protein that effects calcium-dependent adhesion of epithelial cells), excludes Slug (a transcription factor that suppresses expression of the E-cadherin gene), $\beta$-catenin (a signaling protein of the Wnt pathway that decreases expression of the E-cadherin gene) and vimentin (a cytoskeletal protein used for migration, transcriptionally activated by $\beta$-catenin signaling.) [28-32] . The molecular signature of these cells reverted concomitantly from mesenchymal to epithelial.

As expected, higher doses of PHII-7 induced apoptosis, apparently through a caspase-dependent mitochondrial pathway, and inhibited cell proliferation and colony formation. The intrinsic pathway of apoptosis involves some apoptosis-related molecules and signal pathways, including pro-apoptotic protein Bax and caspase family [33,34]. We investigated that PHII-7 induced apoptosis through increasing the expression of Bax which is an important pro-apoptotic protein and the expressions of cl-PARP, cl-caspase 3 and cl-caspase 9 in a dose-dependent manner. All data confirmed that PHII-7 induced apoptosis through activating of the caspase-dependent apoptosis pathway in metastatic cancers.

In summary, this was the first study of the effects of PHII-7 against invasion and migration. In metastatic cancers, slightly toxic doses of the anti-cancer drug PHII-7 decreased the motility and invasive activities of epithelial cancer cell lines, regardless of multidrug resistant cancers by regulating several EMT-related genes, such as E-cadherin. Higher doses of PHII-7 inhibited cell proliferation and induced apoptosis. PHII-7 not only can overcome multidrug resistance but also is a promising anti-cancer derivative for treatment on invasion and migration.

Acknowledgements: This study was supported by grants from National Science and Technology Major Project (Grant No. 2012ZX09102-301-015), Natural Science Foundation of Tianjin (Grant No. 05YFGZGX02800) and Natural Science Foundation of China (Grant No. 30873091 and 30971291). Authors thanked Dr. David Caldwell and Dr. Shaoxiang Wang for revising manuscript.

\section{References}

[1] ODLE TG. Breast cancer survivorship and surveillance. Radiol Technol. 2011; 83: 63M-87M.

[2] WANG J, WANG B, ZHAO W, GUO Y, CHEN H et al. Clinical significance and role of lymphatic vessel invasion as a major prognostic implication in non-small cell lung cancer: a metaanalysis. Plos One. 2012; 7: e52704. http://dx.doi.org/10.1371/ journal.pone. 0052704

[3] Woodhouse EC, Chuaqui RF, Liotta la. General mechanisms of metastasis. Cancer. 1997; 80: 1529-37. http://dx.doi.org/10.1002/(SICI)1097-0142(19971015)80:8+<1529::AID-CNCR2 $>3.0 . C O ; 2-F$

[4] NIETO MA. Epithelial plasticity: a common theme in embryonic and cancer cells. Science. 2013; 342: 1234850. http:// dx.doi.org/10.1126/science.1234850

[5] DE CRAENE B, BERX G. Regulatory networks defining EMT during cancer initiation and progression. Nat Rev Cancer. 2013; 13: 97-110. http://dx.doi.org/10.1038/nrc3447

[6] GUISE TA. Breast cancer bone metastases: it's all about the neighborhood. Cell. 2013; 154: 957-9. http://dx.doi. org/10.1016/j.cell.2013.08.020

[7] GREIJER AE, DE JONG MC, SCHEFFER GL, SHVARTS A, VAN DIEST PJ et al. Hypoxia-induced acidification causes mitoxantrone resistance not mediated by drug transporters in human breast cancer cells. Cell Oncol. 2005; 27: 43-9.

[8] YAMAGISHI N, NAKAO R, KONDO R, NISHITSUJI M, SAITO Y et al. Increased expression of sorcin is associated with multidrug resistance in leukemia cells via up-regulation of MDR1 expression through cAMP response elementbinding protein. Biochem Biophys Res Commun. 2014; 448: 430-6. http://dx.doi.org/10.1016/j.bbrc.2014.04.125

[9] WANG L, ZHANG GM, FENG ZH. Down-regulation of survivin expression reversed multidrug resistance in adriamycin-resistant HL-60/ADR cell line. Acta Pharmacol Sin. 2003; 24: 1235-40.

[10] LU L, ZHOU D, JIANG X, SONG K, LI K et al. Loss of Ecadherin in multidrug resistant breast cancer cell line MCF-7/ Adr: possible implication in the enhanced invasive ability. Eur Rev Med Pharmacol Sci. 2012; 16: 1271-9.

[11] ZHANG X, LIU G, KANG Y, DONG Z, QIAN Q et al. Ncadherin expression is associated with acquisition of EMT phenotype and with enhanced invasion in erlotinib-resistant lung cancer cell lines. Plos One. 2013; 8: e57692. http://dx.doi. org/10.1371/journal.pone.0057692

[12] HOESSEL R, LECLERC S, ENDICOTT JA, NOBEL ME, LAWRIE A et al. Indirubin, the active constituent of a Chinese antileukaemia medicine, inhibits cyclin-dependent kinases. Nat Cell Biol. 1999; 1: 60-7.

[13] EISENBRAND G, HIPPE F, JAKOBS S, MUEHLBEYER S. Molecular mechanisms of indirubin and its derivatives: novel anticancer molecules with their origin in traditional Chinese phytomedicine. J Cancer Res Clin Oncol. 2004; 130: 627-35. http://dx.doi.org/10.1007/s00432-004-0579-2

[14] SHI R, LI W, ZHANG X, ZHANG Y, PENG H et al. A novel indirubin derivative PHII-7 potentiates adriamycin cytotoxicity via inhibiting P-glycoprotein expression in human breast cancer MCF-7/ADR cells. Eur J Pharmacol. 2011; 669: 38-44. http://dx.doi.org/10.1016/j.ejphar.2011.07.047

[15] SU Y, CHENG X, TAN Y, HU Y, ZHOU Y et al. Synthesis of a dual functional anti-MDR tumor agent PH II-7 with elucidations of anti-tumor effects and mechanisms. Plos One. 2012; 7: e32782. http://dx.doi.org/10.1371/journal.pone.0032782 
[16] YUAN Q, CAI S, ZHANG X, LIU Z, LI Z et al. A new protoapigenone analog RY10-4 induces apoptosis and suppresses invasion through the PI3K/Akt pathway in human breast cancer. Cancer Lett. 2012; 324: 210-20. http://dx.doi. org/10.1016/j.canlet.2012.05.025

[17] CHEN J, WANG M, XI B, XUE J, HE D et al. SPARC is a key regulator of proliferation, apoptosis and invasion in human ovarian cancer. Plos One. 2012; 7: e42413. http://dx.doi. org/10.1371/journal.pone.0042413

[18] LIN KL, TSAI PC, HSIEH CY, CHANG LS, LIN SR. Antimetastatic effect and mechanism of ovatodiolide in MDA-MB-231 human breast cancer cells. Chem Biol Interact. 2011; 194: 148-58. http://dx.doi.org/10.1016/j.cbi.2011.10.002

[19] JEMAL A, BRAY F, CENTER MM, FERLAY J, WARD E et al. Global cancer statistics. CA Cancer J Clin. 2011; 61: 69-90. http://dx.doi.org/10.3322/caac.20107

[20] KAGOHASHI K, SATOH H, ISHIKAWA H, OHTSUKA M, SEKIZAWA K. Liver metastasis at the time of initial diagnosis of lung cancer. Med Oncol. 2003; 20: 25-8. http://dx.doi. org/10.1385/MO:20:1:25

[21] ZOCHBAUER-MULLER S, FILIPITS M, RUDAS M, BRUNNER R, KRAJNIK G et al. P-glycoprotein and MRP1 expression in axillary lymph node metastases of breast cancer patients. Anticancer Res. 2001; 21: 119-24.

[22] LI HL, XIE SM, ZHANG L, CAI CJ, WANG W et al. Establishment and characterization of a new drug surviving cell line Am1010, derived directly from muscle metastases of a human lung adenocarcinoma patient with multi-drug-resistance to cisplatin, taxol, and gefitinib. Acta Pharmacol Sin. 2010; 31: 601-8. http://dx.doi.org/10.1038/aps.2010.41

[23] ZEISBERG M, NEILSON EG. Biomarkers for epithelialmesenchymal transitions. J Clin Invest. 2009; 119: 1429-37. http://dx.doi.org/10.1172/JCI36183

[24] HUNAKOVA L, SEDLAKOVA O, CHOLUJOVA D, GRONESOVA P, DURAJ J et al. Modulation of markers associated with aggressive phenotype in MDA-MB-231 breast carcinoma cells by sulforaphane. Neoplasma. 2009; 56: 548-56. http://dx.doi.org/10.4149/neo $200906 \quad 548$

[25] YIN L, CASTAGNINO P, ASSOIAN RK. ABCG2 expression and side population abundance regulated by a transforming growth factor beta-directed epithelial-mesenchymal transition. Cancer Res. 2008; 68: 800-7. http://dx.doi.org/10.1158/00085472.CAN-07-2545

[26] SAXENA M, STEPHENS MA, PATHAK H, RANGARAJAN A. Transcription factors that mediate epithelial-mesenchymal transition lead to multidrug resistance by upregulating $\mathrm{ABC}$ transporters. Cell Death Dis. 2011; 2: e179. http://dx.doi. org/10.1038/cddis.2011.61

[27] MA MZ, YAO BY. Progress in indirubin treatment of chronic myelocytic leukemia. J Tradit Chin Med. 1983; 3: $245-8$.

[28] GILlES C, POLETTE M, MESTDAGT M, NAWROCKIRABY B, RUGGERI $P$ et al. Transactivation of vimentin by beta-catenin in human breast cancer cells. Cancer Res. 2003; 63: 2658-64.

[29] Gilles C, POLETTE M, ZAHM JM, TOURNiER JM, VOLDERS L et al. Vimentin contributes to human mammary epithelial cell migration. J Cell Sci. 1999; 112 (Pt 24): 4615-25.

[30] CARTER V, SHENTON BK, JAQUES B, TURNER D, TALBOT D et al. Vimentin antibodies: a non-HLA antibody as a potential risk factor in renal transplantation. Transplant Proc. 2005; 37: 654-57. http://dx.doi.org/10.1016/j. transproceed.2004.12.043

[31] GEMOLL T, HABERMANN JK, LAHMANN J, SZYMCZAK $S$, LUNDGREN C et al. Protein profiling of genomic instability in endometrial cancer. Cell Mol Life Sci. 2012; 69: 325-33. http://dx.doi.org/10.1007/s00018-011-0752-0

[32] VORA HH, PATEL NA, RAJVIK KN, MEHTA SV, BRAHMBHATT BV et al. Cytokeratin and vimentin expression in breast cancer. Int J Biol Markers. 2009; 24: 38-46.

[33] AI X, BUTTS B, VORA K, LI W, TACHE-TALMADGE C et al. Generation and characterization of antibodies specific for caspase-cleaved neo-epitopes: a novel approach. Cell Death Dis. 2011; 2: e205. http://dx.doi.org/10.1038/ cddis.2011.91

[34] WOLTER KG, HSU YT, SMITH CL, NECHUSHTAN A, XI $\mathrm{XG}$ et al. Movement of Bax from the cytosol to mitochondria during apoptosis. J Cell Biol. 1997; 139: 1281-92. http://dx.doi. org/10.1083/jcb.139.5.1281 